\title{
NFAT5 Contributes to Osmolality-Induced MCP-1 Expression in Mesothelial Cells
}

\author{
Christoph Küper, ${ }^{1}$ Franz-X. Beck, ${ }^{1}$ and Wolfgang Neuhofer ${ }^{1,2}$ \\ ${ }^{1}$ Department of Physiology, University of Munich, 80336 Munich, Germany \\ ${ }^{2}$ Department of Nephrology, Medical Clinic and Policlinic IV, University of Munich, Inner City Campus, 80335 Munich, Germany
}

Correspondence should be addressed to Christoph Küper, christoph.kueper@lrz.uni-muenchen.de

Received 21 December 2011; Accepted 28 January 2012

Academic Editor: Markus Wörnle

Copyright () 2012 Christoph Küper et al. This is an open access article distributed under the Creative Commons Attribution License, which permits unrestricted use, distribution, and reproduction in any medium, provided the original work is properly cited.

Increased expression of the C-C chemokine monocyte chemoattractant protein-1 (MCP-1) in mesothelial cells in response to high glucose concentrations and/or high osmolality plays a crucial role in the development of peritoneal fibrosis during continuous ambulatory peritoneal dialysis (CAPD). Recent studies suggest that in kidney cells osmolality-induced MCP-1 upregulation is mediated by the osmosensitive transcription factor, nuclear factor of activated T cells 5 (NFAT5). The present study addressed the question of whether activation of NFAT5 by hyperosmolality, as present in PD fluids, contributes to MCP-1 expression in the mesothelial cell line Met5A. Hyperosmolality, induced by addition of glucose, $\mathrm{NaCl}$, or mannitol to the growth medium, increased NFAT5 activity and stimulated MCP-1 expression in Met5A cells. siRNA-mediated knockdown of NFAT5 attenuated osmolalityinduced MCP-1 upregulation substantially. Hyperosmolality also induced activation of nuclear factor- $\kappa \mathrm{B}$ (NF- $\kappa \mathrm{B})$. Accordingly, pharmacological inhibition of NF- $\kappa \mathrm{B}$ significantly decreased osmolality-induced MCP-1 expression. Taken together, these results indicate that high osmolalities activate the transcription factor NFAT5 in mesothelial cells. NFAT5 in turn upregulates MCP-1, likely in combination with NF- $\kappa \mathrm{B}$, and thus may participate in the development of peritoneal fibrosis during CAPD.

\section{Introduction}

Peritoneal dialysis (PD) is a well-established and effective renal replacement therapy that is employed regularly in patients suffering from end-stage chronic kidney disease. The long-time efficiency of PD is limited by the bio-incompatibility of the currently used PD fluids (PDF) [1]. The latter induces severe pathophysiological changes in the peritoneal membrane, such as fibrosis and angiogenesis, which eventually are responsible for the functional failure of continuous ambulatory peritoneal dialysis (CAPD) $[2,3]$. Conventional PDFs are characterized by high concentrations of glucose degradation products (GDPs), an unphysiological low $\mathrm{pH}$, and high osmolalities [4]. In the last two decades significant efforts have been undertaken to improve the biocompatibility of PDFs by minimizing the formation of GDP during heat sterilization $[2,4]$ and by establishing a more physiological $\mathrm{pH}$ [5]. Although the physicochemical properties have been improved, efficient ultrafiltration across the peritoneal membrane requires supraphysiological osmolalities in the range of 380-510 mosm $/ \mathrm{kg} \mathrm{H}_{2} \mathrm{O}$, depending on the respective PDF. Accordingly, peritoneal mesothelial cells are exposed to local osmotic stress for several hours during PD.

The assumption that local osmotic stress contributes to the bio-incompatibility of PDFs is supported by the notion that even with the use of novel PDF, with a nearly physiological $\mathrm{pH}$ and low content of GDP, the mesothelium produces large amounts of established markers of peritoneal damage [6]. Proinflammatory mediators such as TGF- $\beta 1$ or MCP1 are synthesized in peritoneal mesothelial cells not only in response to glucose but also in response to osmotic stress [7].

The exposure of mesothelial cells to local osmotic stress during PD suggests an activation of the osmosensitive transcription factor NFAT5 (nuclear factor of activated T cells 5; also known as TonEBP or OREBP) in peritoneal mesothelial cells. NFAT5 was originally identified in collecting duct cells of the renal medulla [8], which are exposed to interstitial osmolalities severalfold higher compared to plasma osmolality (up to $1.200 \mathrm{mosm} / \mathrm{kg} \mathrm{H}_{2} \mathrm{O}$ ) during antidiuresis. In renal 
cells NFAT5 regulates the expression of various genes necessary for an efficient urinary concentration, for example, AQP-2 or UT-A, as well as genes required for the adaptation to high osmolalities, for example, aldose reductase or HSP70 [9]. NFAT5-regulated genes contain tonicity enhancer (TonE) elements in their promoter region, to which upon activation NFAT5 binds and stimulates the transcriptional machinery.

Recent studies suggest that under various pathophysiological conditions NFAT5 is activated by local osmotic stress and stimulates the expression of proinflammatory cytokines $[10,11]$, probably in cooperation with NF- $\kappa \mathrm{B}[12]$. In particular, upregulation of MCP-1 in renal tubular epithelial cells exposed to osmotic stress has been shown to be NFAT5 dependent $[12,13]$. The $\mathrm{C}-\mathrm{C}$ chemokine MCP- 1 is a potent chemoattractant for circulating $\mathrm{T}$ cells and macrophages/ monocytes [14] and plays a key role in the recruitment of these cells to the peritoneal cavity [15]. Besides its chemoattractant activity, MCP-1 stimulates expression of adhesion molecules and proinflammatory cytokines in monocytes [16] and induces calcium flux and the respiratory burst [17]. In fibroblasts, MCP-1 may increase synthesis of collagen and TGF- $\beta 1$ [18], another key factor for the remodelling of peritoneal tissue. Pathophysiological upregulation of MCP-1 expression contributes to fibrotic lesions in the lung [19], the liver [20], and the kidney [21]. Since MCP-1 is also involved in the development of peritoneal damage [22-27], the aim of the present study was to determine whether activation of NFAT5 in response to osmotic stress, as present during PD, contributes to enhanced expression of MCP-1 in peritoneal mesothelial cells.

\section{Methods}

2.1. Materials. The NF- $\kappa$ B inhibitor Bay 11-7082 was obtained from Sigma (Deisenhofen, Germany). Anti-NFAT5 antibody weas from Santa Cruz Biotechnology (Santa Cruz, CA, USA); anti-actin antibody was from Sigma; anti-p65 and anti-phospho-p65 (Ser536) and horseradish peroxidase-conjugated anti-rabbit $\operatorname{IgG}$ were purchased from Cell Signaling (Beverly, MA, USA); anti-histone H1 was from Millipore (Billerica, MA, USA). Unless otherwise indicated, other reagents were purchased from Biomol (Hamburg, Germany), Biozol (Eching, Germany), Carl Roth (Karlsruhe, Germany), or Sigma.

2.2. Cell Culture. Immortalized human mesothelial cells (Met5A, ATCC CRL-9444) were cultured in M199 culture medium supplemented with $4 \mathrm{mM}$ 4-(2-hydroxyethyl)-1piperazineethanesulfonic acid (HEPES), with 10\% fetal bovine serum (Biochrom, Berlin, Germany), 100 units/mL penicillin, and $100 \mu \mathrm{g} / \mathrm{mL}$ streptomycin (Invitrogen, Karlsruhe, Germany) at $37^{\circ} \mathrm{C}$ in a humidified atmosphere (95\% air $/ 5 \%$ $\mathrm{CO}_{2}$ ). Cells were grown in 24-well plates to confluency. For experiments, medium osmolality was increased by addition of glucose or, as osmotic controls, $\mathrm{NaCl}$ or mannitol.

2.3. qRT-PCR Analysis. For determination of MCP- 1 and $\beta$ Actin mRNA expression levels, the total RNA from Met5A cells was prepared by adding TRIFAST Reagent (PEQLAB, Erlangen, Germany). The primers (Metabion, Martinsried, Germany) used in this experiment were MCP-1_fw: $5^{\prime}-$ AGT CTC TGC CGC CCT TCT-3'; MCP-1_rev: 5'-GTG ACT GGG GCA TTG ATT G-3'; actin_fw: $5^{\prime}$-CCA ACC GCG AGA AGA TGA-3'; actin_rev: 5'-CCA GAG GCG TAC AGG GAT AG-3'. Experiments were carried out on a Roche LightCycler 480, using the SensiMix SYBR OneStep Kit (Bioline, Luckenwalde, Germany) according to the manufacturer's recommendations. Specificity of PCR product formation was confirmed by monitoring melting point analysis and by agarose gel electrophoresis.

2.4. Immunoblot Analysis. Aliquots (5-30 $\mu \mathrm{g}$ protein) were subjected to $10 \%$ sodium dodecyl sulfate polyacrylamide gel electrophoresis (SDS-PAGE) and blotted onto nitrocellulose membranes (Amersham Pharmacia Biotech, Buckinghamshire, UK). Nonspecific binding sites were blocked with $5 \%$ nonfat dry milk in PBS containing $0.1 \%$ Tween-20 (PBS$\mathrm{T})$ at room temperature for $1 \mathrm{~h}$. Samples were incubated with primary antibodies in PBS-T containing 5\% nonfat dry milk over night at $4^{\circ} \mathrm{C}$. Subsequently, the blots were washed 3 times with PBS-T for $5 \mathrm{~min}$ each, and the membranes then incubated with appropriate secondary antibody at room temperature for $1 \mathrm{~h}$ in PBS-T containing 5\% nonfat dry milk. After washing with PBS-T 3 times for 5 min each, immunocomplexes were visualized by enhanced chemiluminescence (Pierce, Rockford, IL, USA).

2.5. Preparation of Cytosolic and Nuclear Extracts. Subcellular extracts were prepared with the ProteoJET cytoplasmic and nuclear protein extraction kit (Fermentas, St. Leon-Rot, Germany) according to the manufacturer's recommendations, with broad specificity protease inhibitor cocktail (Sigma) added at $1: 100(\mathrm{v} / \mathrm{v})$.

2.6. MCP-1 Measurement. Concentration of MCP-1 in the cell culture supernatant was determined using a specific ELISA kit (PeproTech, Hamburg, Germany) according to the manufacturer's recommendations.

2.7. Reporter Gene Assays. Activation of transcription factors NFAT5 or NF- $\kappa$ B in response to hyperosmolality was assessed using the secreted alkaline phosphatase system (SEAP), with reporter constructs in which the SEAP open reading frame is under control of the respective transacting elements. pNF$\kappa$ B-SEAP (Clontech, Heidelberg, Germany) contains four copies of the $\kappa \mathrm{B}$ response element; PSEAP-TonE contains two TonE sites [28]. For transfection, Met5A cells were grown to $\sim 80 \%$ confluency, trypsinated, washed in PBS, and $10^{6}$ cells were finally resuspended in $200 \mu \mathrm{L}$ modified HBS electroporation buffer (0.5\% HEPES, $1 \%$ glucose, $0.5 \%$ Ficoll, $5 \mathrm{mM}$ $\mathrm{NaCl}, 135 \mathrm{mM} \mathrm{KCl}, 2 \mathrm{mM} \mathrm{MgCl}$, pH 7.4) together with $10 \mu \mathrm{g}$ of the respective reporter vector. Electroporation was performed using a Gene Pulser X cell electroporation system (Bio-Rad, Hercules, CA, USA) at $150 \mathrm{~V}$ and $950 \mu \mathrm{F}$ (exponential decay pulse) in a $2 \mathrm{~mm}$ cuvette, and the cells were subsequently seeded immediately in 96-well plates. After growing to confluency, the cells were treated as indicated and 
SEAP activity in the medium determined as described before [29].

2.8. NFAT5 Transactivation Assay. NFAT5 transactivation activity was determined using the GAL4 binary assay as initially described by Ferraris et al. [30]. pGAL4-TonEBPTAD contains the yeast GAL4 DNA-binding domain fused in frame to the transactivation domain (TAD) of NFAT5 (amino acids 548-1531; kindly provided by Dr. J. Ferraris, National Institutes of Health, Bethesda, MD, USA). pFRSEAP (Agilent Technologies, Santa Clara, CA, USA) contains five tandem repeats of the GAL4 binding site upstream of a minimal promoter and the SEAP gene. Briefly, $10^{6}$ cells were electroporated with $10 \mu \mathrm{g}$ pGAL4-TonEBP-TAD and $10 \mu \mathrm{g}$ pFR-SEAP as described above. After growing to confluency, the cells were treated as indicated and SEAP activity in the medium determined as described before [29].

2.9. NFAT5 Knockdown. Accell SMARTpool siRNA construct for knockdown of NFAT5 or Accell nontargeting siRNA (no. 2) were obtained from Thermo Fisher Scientific (Epsom, UK). Knockdown in Met5A cells was performed according to the manufacturer's instructions. The concentration of siRNA constructs was $1 \mu \mathrm{M}$ in Accell delivery medium, containing 2\% FCS. Cells were incubated for 5 days, and knock-down efficiency was determined by qRT-PCR and by western blot analysis.

2.10. Statistical Analyses. Data are expressed as means \pm SEM. The significance of differences between the means was assessed by Student's $t$-test. $P<0.05$ was regarded as significant. All experiments were performed at least three times, and representative results are shown.

\section{Results}

3.1. Osmolality-Induced Upregulation of MCP-1 Expression in Met5A Cells. The effect of medium osmolality on MCP-1 secretion of Met5A cells was tested by measurement of MCP1 concentration in the cell culture supernatants. The cells were incubated in isosmotic ( $300 \mathrm{mosm} / \mathrm{kg} \mathrm{H}_{2} \mathrm{O}$ ) or hyperosmotic ( $400 \mathrm{mosm} / \mathrm{kg} \mathrm{H}_{2} \mathrm{O}$ ) medium. The medium osmolality was elevated by the addition of glucose. To distinguish between glucose-specific effects and osmolality-induced effects, mannitol or $\mathrm{NaCl}$ was used as osmotic controls. Samples of cell culture supernatant were taken at various times between 2 and $24 \mathrm{~h}$. Under isosmotic conditions constitutive MCP-1 secretion could be observed: MCP-1 concentration in the cell culture supernatant rose from $25 \pm 8 \mathrm{pg} / \mathrm{mL}$ after $2 \mathrm{~h}$ to $220 \pm 43 \mathrm{pg} / \mathrm{mL}$ after $24 \mathrm{~h}$ (Figure $1(\mathrm{a})$ ). This constitutive MCP-1 secretion was significantly enhanced under hyperosmotic conditions. The strongest effect was observed when medium osmolality was elevated by addition of glucose: MCP-1 concentration reached $760 \pm 26 \mathrm{pg} / \mathrm{mL}$ after $24 \mathrm{~h}$. The effects of mannitol $(480 \pm 67 \mathrm{pg} / \mathrm{mL}$ after $24 \mathrm{~h})$ and $\mathrm{NaCl}(390 \pm 36 \mathrm{pg} / \mathrm{mL}$ after $24 \mathrm{~h})$ were less pronounced than that of glucose but were still significantly increased compared to the isosmotic control.
An osmolality-induced increase of MCP-1 expression was also observed at the mRNA level (Figure 1(b)). Surprisingly, at all tested times $\mathrm{NaCl}$ (rather than glucose) had the strongest effect on MCP-1 mRNA abundance, while on the protein level glucose had the stronger effect (see above), probably indicating that glucose, and not osmolality per se, also stimulates posttranscriptional and/or posttranslational mechanisms, thus further enhancing MCP-1 secretion.

3.2. Osmolality-Induced Activation of NFAT5 in Met5A Cells. In kidney cells, hyperosmolality stimulates overall NFAT5 activity by (i) increased NFAT5 expression, (ii) increased NFAT5 translocation into the nucleus, and (iii) activation of the NFAT5 transactivation domain. Accordingly, hyperosmolality elevated NFAT5 expression also in Met5A cells, at both the protein and mRNA levels (Figures 2(a)-2(c)). The most prominent effect was observed when medium osmolality was raised by addition of $\mathrm{NaCl}$; glucose and mannitol also caused a robust increase of NFAT5 abundance. Additionally, hyperosmolality increased translocation of NFAT5 from the cytoplasm into the nucleus (Figures 2(d) and 2(e)) and activity of the NFAT5 transactivation domain (Figure 2(f)).

Activation of NFAT5 in Met5A cells by hyperosmolality was assayed using a TonE-driven reporter vector. Medium osmolalities were elevated to $325-550$ mosm $/ \mathrm{kg} \mathrm{H}_{2} \mathrm{O}$ by addition of glucose, mannitol, or $\mathrm{NaCl}$, and Met5A cells, transfected transiently with the reporter construct, were incubated for $24 \mathrm{~h}$. Raising the medium osmolality increased NFAT5 activity approximately 2-3 fold (Figure 2(g)). For glucose and mannitol, NFAT5 activity reached a maximum at a final osmolality of $400 \mathrm{mosm} / \mathrm{kg} \mathrm{H}_{2} \mathrm{O}$, for $\mathrm{NaCl}$ at 450 $\mathrm{mosm} / \mathrm{kg} \mathrm{H}_{2} \mathrm{O}$. At even higher osmolalities, NFAT5 activity declined.

3.3. Osmolality-Induced MCP-1 Upregulation Is Decreased by NFAT5 Knockdown. To evaluate the role of NFAT5 in osmolality-induced MCP-1 expression, NFAT5 was knocked down using a siRNA approach. Knock-down efficiency, as tested by immunoblotting (Figure $3(\mathrm{a})$ ), was at $\sim 80 \%$ compared with control cells transfected with a scrambled siRNA. As expected, hyperosmolality, induced either by glucose or $\mathrm{NaCl}$ addition, significantly increased MCP-1 both in the cell culture supernatant (Figure 3(b)) and at the mRNA level (Figure 3(c)) of control cells. Knockdown of NFAT5 largely attenuated osmolality-induced increase in MCP-1 expression (Figures 3(b) and 3(c)), indicating a central role for NFAT5 in this process.

3.4. Role of NF- $\kappa B$ in Osmolality-Induced MCP-1 Expression. Another transcription factor probably involved in upregulation of MCP-1 during hyperosmotic stress is NF- $\kappa \mathrm{B}$ [27]. In Met5A cells transfected transiently with a $\kappa \mathrm{B}$-driven reporter vector, hyperosmolality, induced by addition of $\mathrm{NaCl}$ or glucose, significantly increased reporter activity (Figure 4(a)). Accordingly, phosphorylation of the p65 subunit was enhanced significantly under these conditions (Figure 4(b)), indicating that hyperosmolality activates NF- $\kappa \mathrm{B}$. Next, NF- $\kappa \mathrm{B}$ in Met5A cells was inhibited by treatment with the pharmacological inhibitor Bay 11-7082. NF- $\kappa$ B inhibition not only 

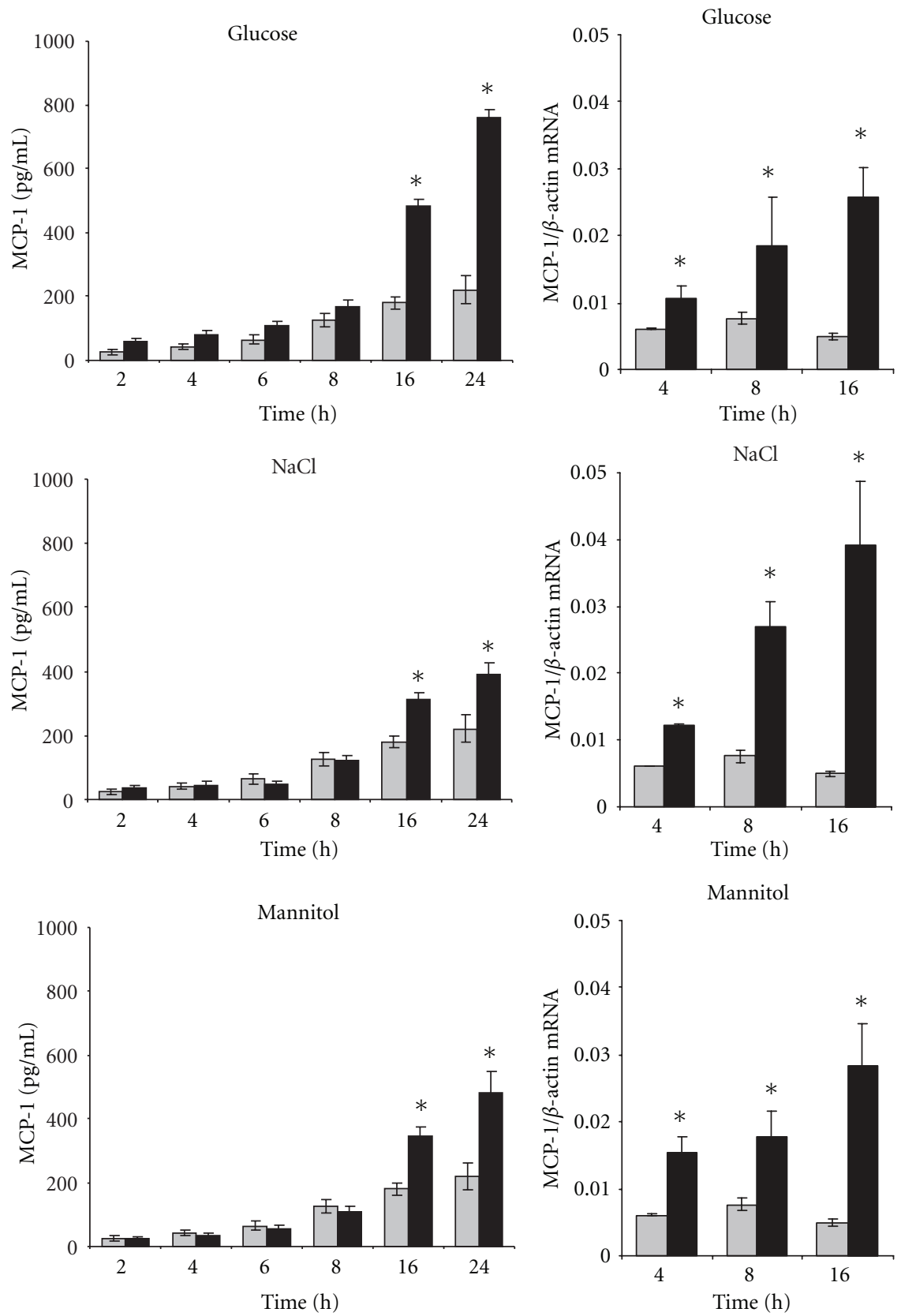

(a)

(b)

Figure 1: Osmolality-induced MCP-1 expression. (a) For determination of MCP-1 secretion, confluent Met5A cells were incubated in isosmotic medium (gray column; $300 \mathrm{mosm} / \mathrm{kg} \mathrm{H}_{2} \mathrm{O}$ ) or were exposed to hyperosmotic medium (black column; $400 \mathrm{mosm} / \mathrm{kg} \mathrm{H} \mathrm{H}_{2} \mathrm{O}$ ). Medium osmolality was elevated by addition of glucose, $\mathrm{NaCl}$, or mannitol as indicated. At the indicated times, medium samples were collected and the concentration of MCP-1 in the cell culture supernatant determined by ELISA as described in Section 2. Means \pm SEM for $n=4$ per point; ${ }^{*} P<0.05$ versus isosmotic control. (b) For determination of MCP-1 transcription, confluent Met5A cells remained in isosmotic medium (gray column; 300 mosm $/ \mathrm{kg} \mathrm{H}_{2} \mathrm{O}$ ) or were exposed to hyperosmotic medium (black column; $400 \mathrm{mosm} / \mathrm{kg} \mathrm{H}_{2} \mathrm{O}$ ). Medium osmolality was elevated by addition of glucose, $\mathrm{NaCl}$, or mannitol as indicated. At the indicated time points, RNA was extracted from the cells and the abundance of MCP-1 mRNA transcript was determined by qRT-PCR as described in Section 2. Relative MCP-1 mRNA abundance was normalized to that of $\beta$-actin to correct for differences in RNA input. Data are means \pm SEM for $n=4$ per point; $* P<0.05$ versus isosmotic control. 


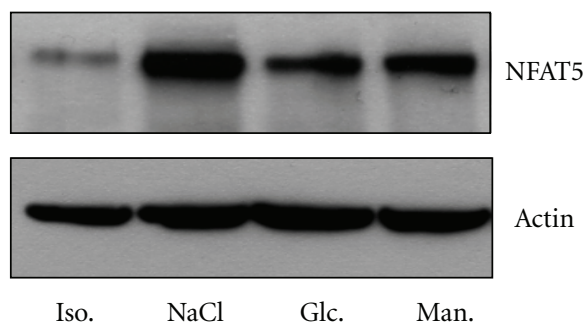

(a)

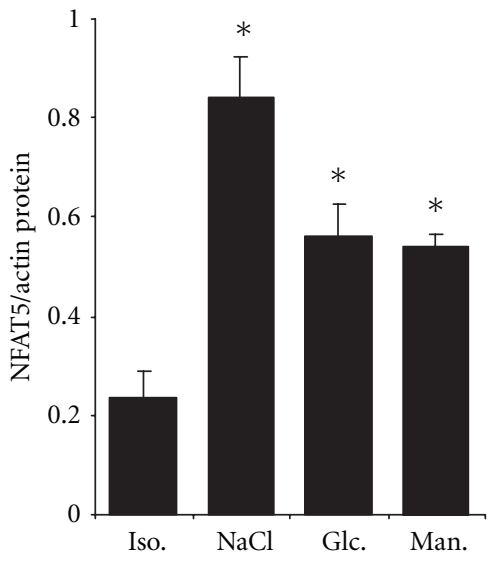

(b)
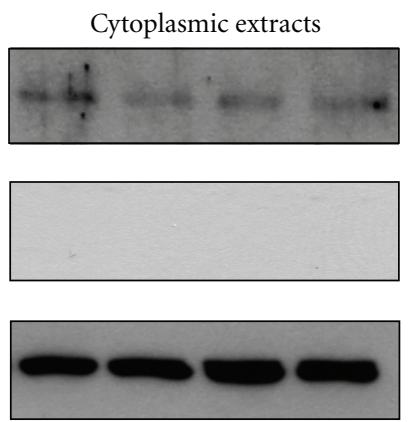

Iso. $\mathrm{NaCl}$ Glc. Man.

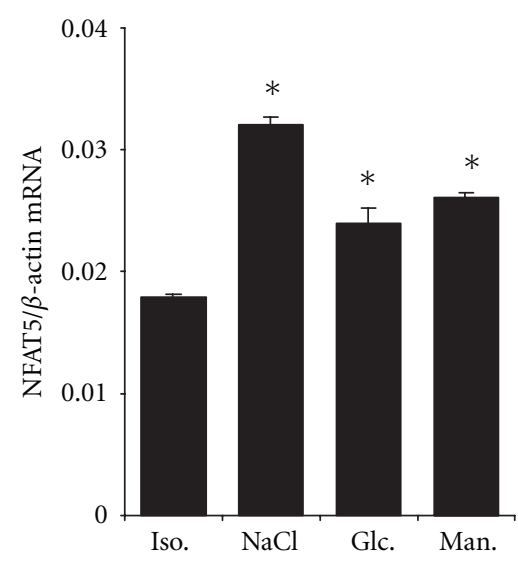

(c)
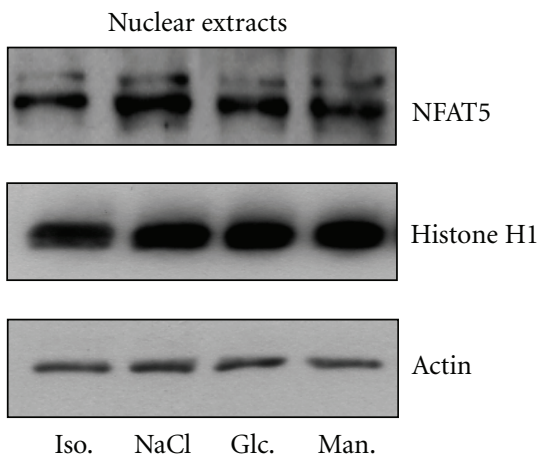

(d)

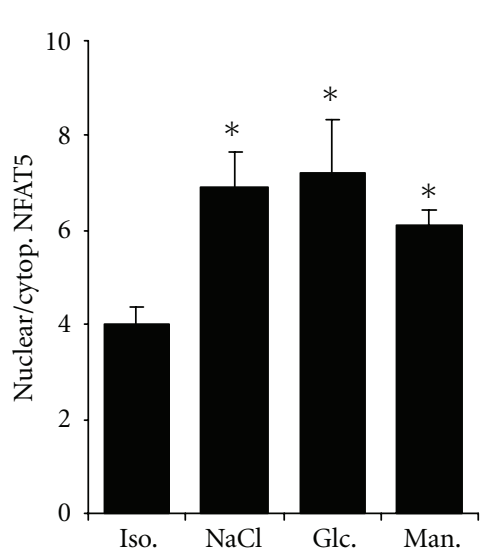

(e)

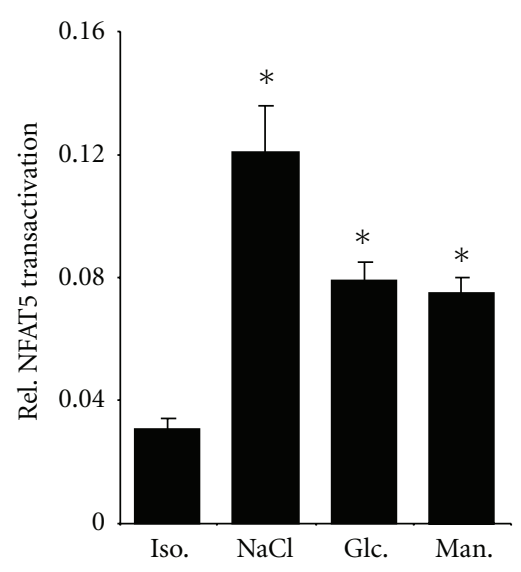

(f)

Figure 2: Continued. 

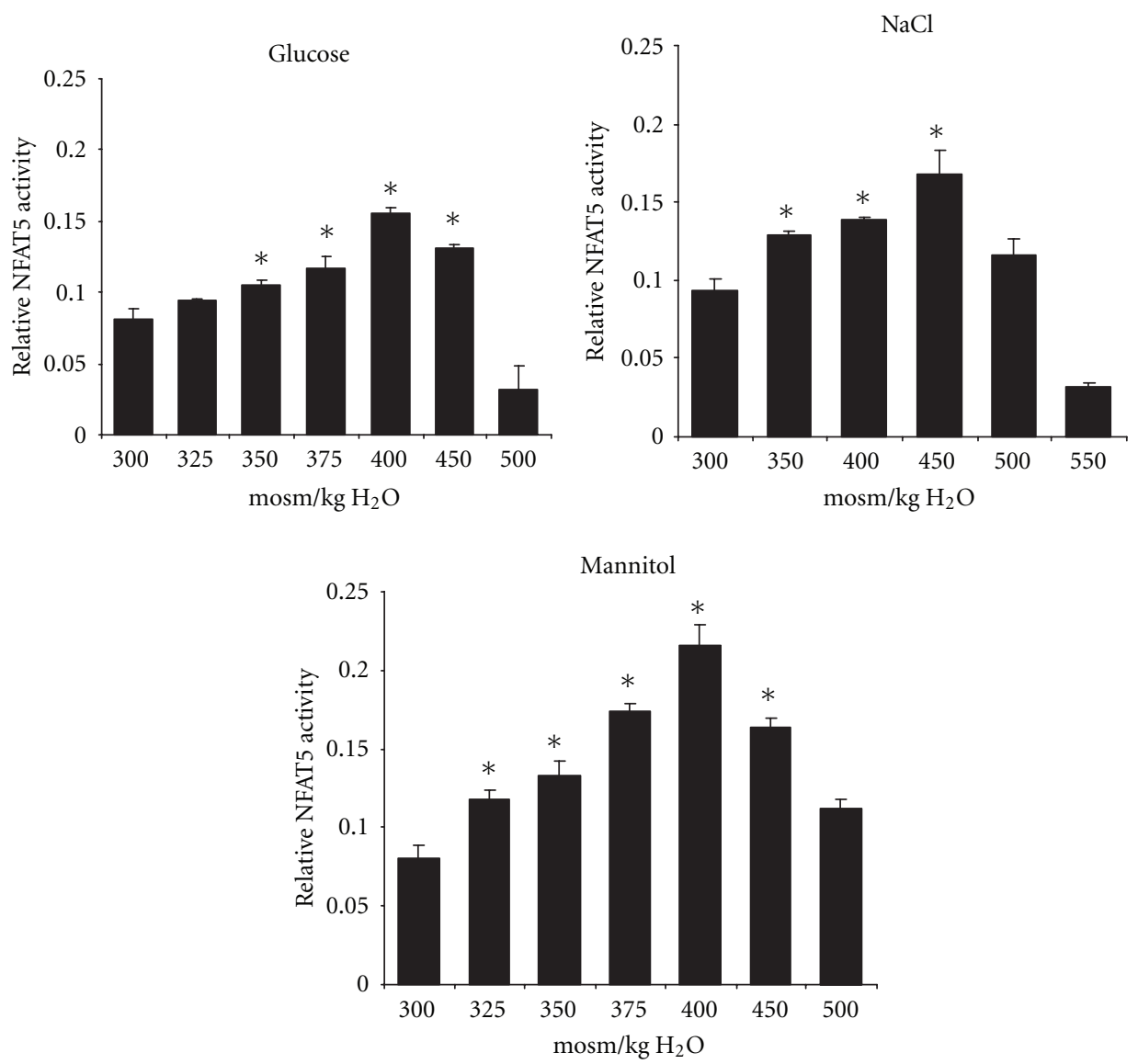

(g)

Figure 2: Expression and activation of NFAT5 in Met5A cells. Met5A cells were kept in isosmotic medium $\left(300 \mathrm{mosm} / \mathrm{kg} \mathrm{H}{ }_{2} \mathrm{O}\right)$ or were exposed to hyperosmotic medium $\left(400 \mathrm{mosm} / \mathrm{kg} \mathrm{H}_{2} \mathrm{O}\right)$. Medium osmolality was elevated by addition of glucose, $\mathrm{NaCl}$, or mannitol as indicated. (a) Cells were incubated for $24 \mathrm{~h}$ and subsequently processed for immunoblotting as described in Section 2 . To demonstrate comparable protein loading, the blots were also probed for actin. A representative blot from 3 independent experiments is shown. (b) Relative NFAT5 protein abundance was quantified by densitometric analysis of immunoblots and normalized to that of actin to correct for differences in protein loading. Means \pm SEM for $n=3 ;{ }^{*} P<0.05$ versus isosmotic control. (c) Cells were incubated for $16 \mathrm{~h}$. Thereafter, RNA was extracted and the abundance of MCP-1 mRNA transcript determined by qRT-PCR as described in Section 2. Relative MCP-1 mRNA abundance was normalized to that of $\beta$-actin to correct for differences in RNA input. Means \pm SEM for $n=3$ per point; $* P<0.05$ versus isosmotic control. (d) Cells were incubated for $1 \mathrm{~h}$, and subsequently cytoplasmic and nuclear extracts prepared and processed for immunoblotting as described in Section 2. To demonstrate purity of extracts and comparable protein loading, the blots were also probed for histone $\mathrm{H} 1$ and actin. A representative blot from 4 independent experiments is shown. (e) Relative NFAT5 nuclear versus cytoplasmic abundance was quantified by densitometric analysis of immunoblots. Means \pm SEM for $n=3$; ${ }^{*} P<0.05$ versus isosmotic control. (f) Activity of the transactivation domain of NFAT5 during osmotic stress. Met5A cells were cotransfected with a vector encoding the fusion protein GAL4dbd-TonEBP-TAD (amino acids 548-1541 of NFAT5 fused to the yeast GAL4 DNA binding domain) together with the reporter vector pFR-SEAP. Cells were kept in isosmotic medium $\left(300 \mathrm{mosm} / \mathrm{kg} \mathrm{H}_{2} \mathrm{O}\right)$ or were exposed to hyperosmotic medium $\left(400 \mathrm{mosm} / \mathrm{kg} \mathrm{H}_{2} \mathrm{O}\right)$. After $48 \mathrm{~h}$, SEAP activity was measured as described in Section 2. Means \pm SEM for $n=3$; ${ }^{*} P<0.05$ versus isosmotic control. (g) Met5A cells were transiently transfected with a reporter construct in which the SEAP gene is under control of two TonE sites. Cells were kept in isosmotic ( $300 \mathrm{mosm} / \mathrm{kg} \mathrm{H}_{2} \mathrm{O}$ ) medium or were exposed to hyperosmotic medium, with osmolalities between 325 and $550 \mathrm{mosm} / \mathrm{kg} \mathrm{H}_{2} \mathrm{O}$ as indicated. After $24 \mathrm{~h}$, SEAP activity was measured as described in Section 2 . Means \pm SEM for $n=4$; ${ }^{*} P<0.05$ versus isosmotic control.

abolished MCP-1 expression under hyperosmotic conditions but also significantly reduced constitutive MCP-1 expression under isosmotic conditions (Figures 4(c) and 4(d)).

\section{Discussion}

Although the biocompatibility of PD solutions has been improved during the recent years by the use of bicarbonate rather than lactate buffers and by limiting excessive GDP formation, hyperosmolality of PDF is required for effective ultrafiltration into the dialysate. The latter is in most cases achieved by the addition of glucose to osmolalities of 380$510 \mathrm{mosm} / \mathrm{kg} \mathrm{H}_{2} \mathrm{O}$. Such high glucose concentrations induce the expression of proinflammatory mediators in mesothelial cells that in turn promote serious long-term complications such as progressive peritoneal fibrosis or even sclerosing 


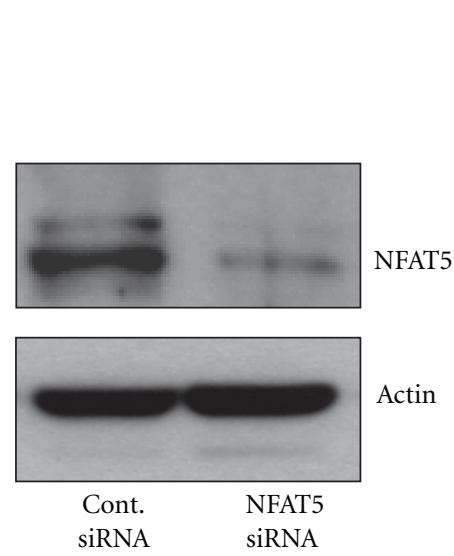

(a)
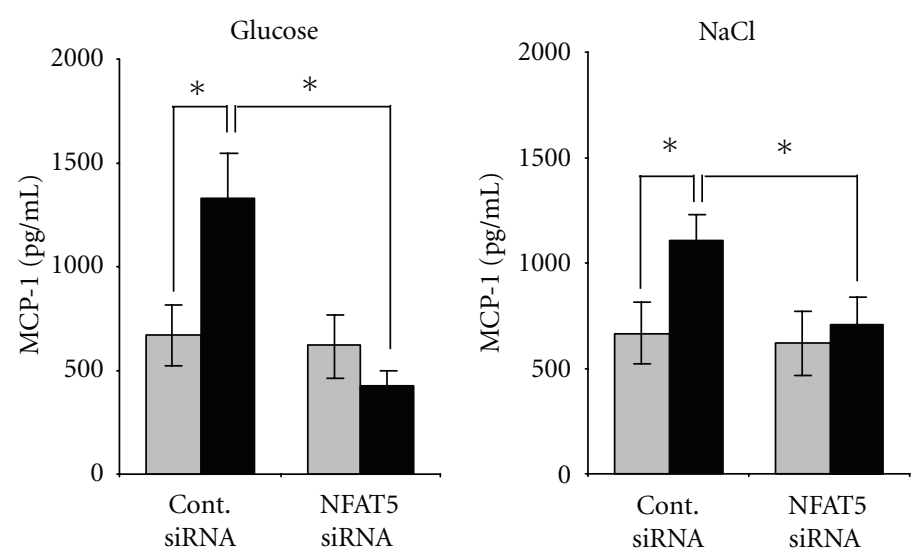

(b)
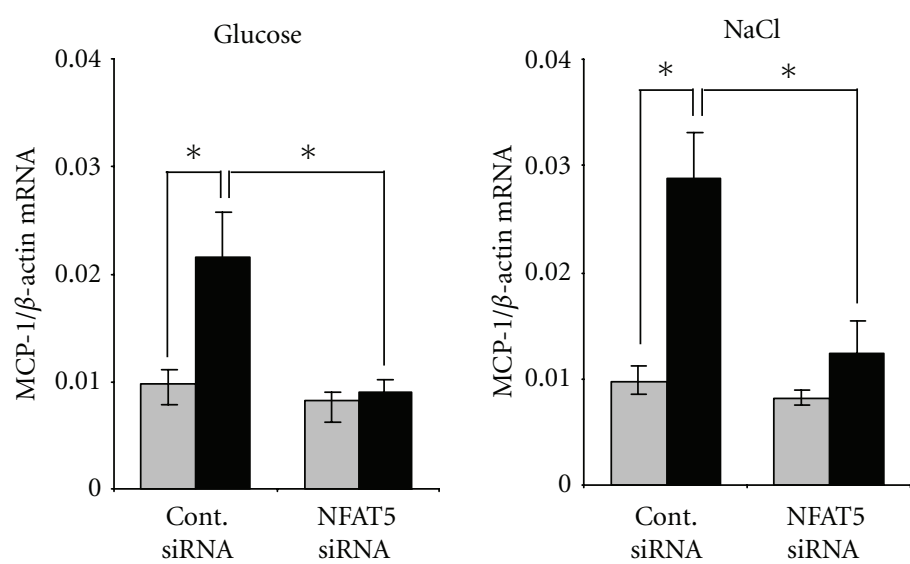

(c)

FIGURE 3: NFAT5-knockdown attenuates osmolality-induced MCP-1 expression. Met5A cells were transfected with siRNA constructs for NFAT5 or with nontargeting siRNA as control as indicated. Cells were kept in isosmotic medium (gray column; $300 \mathrm{mosm} / \mathrm{kg} \mathrm{H} \mathrm{H}_{2} \mathrm{O}$ ) or were exposed to hyperosmotic medium (black column; 400 mosm $/ \mathrm{kg} \mathrm{H}_{2} \mathrm{O}$ ). Medium osmolality was elevated by addition of glucose or $\mathrm{NaCl}$ as indicated, and cells were incubated for $24 \mathrm{~h}$. (a) To demonstrate efficiency of NFAT5 knockdown, cells were processed for immunoblotting as described in Section 2. To demonstrate comparable protein loading, the blots were also probed for actin. (b) For determination of MCP-1 secretion, medium samples were collected and the concentration of MCP-1 in the cell culture supernatant was determined by ELISA as described in Section 2. Means \pm SEM for $n=4$ per point; ${ }^{*} P<0.05$. (c) For determination of MCP- 1 transcription, RNA was extracted from the cells and the abundance of MCP-1 mRNA transcript was determined by qRT-PCR as described in Section 2 . Relative MCP-1 mRNA abundance was normalized to that of $\beta$-actin to correct for differences in RNA input. Means \pm SEM for $n=4$ per point; ${ }^{*} P<0.05$.

peritonitis. Particularly, the expression of TGF- $\beta 1$ and MCP1 is induced in mesothelial cells in response to high glucose concentrations or high osmolality, respectively $[7,27]$. The C-C chemokine MCP-1 recruits monocytes and CD8 T lymphocytes to the peritoneal cavity, where these cells secrete a variety of cytokines and growth factors, which induce or aggravate damage of the peritoneal membrane. In the present study, we provide evidence that the osmosensitive transcription factor NFAT5 contributes to osmolality-induced MCP-1 expression in the mesothelial cell line Met5A. To distinguish between glucose-specific effects and osmolalityinduced effects, experiments were carried out not only with glucose but also with $\mathrm{NaCl}$ or mannitol as osmotic controls. Generally, activation of NFAT5 and upregulation of MCP1 were induced by all three agents, indicating that MCP-1 expression is largely induced in response to hyperosmotic stress. However, some differences between $\mathrm{NaCl}$-induced and glucose-induced MCP-1 expression could be observed and are discussed below. siRNA-mediated knockdown of NFAT5 attenuated the osmolality-induced activation of MCP-1 expression, clearly demonstrating the important role for NFAT5 in this context. The regulation of MCP-1 expression under hyperosmotic conditions by NFAT5 has been recently described in rat and human kidney cells $[12,13]$. At least one TonE element at position $-199 \mathrm{bp}$ to $-186 \mathrm{bp}$ upstream from the transcriptional start site has been identified in the MCP-1 regulatory region, to which NFAT5 binds in response to osmotic stress [13]. Activation of NFAT5 under these conditions probably depends on the MAP kinases p38 and ERK1/2 [12, 13].

NFAT5 is reportedly regulated by various mechanisms in response to osmotic stress in kidney cells: by increased 


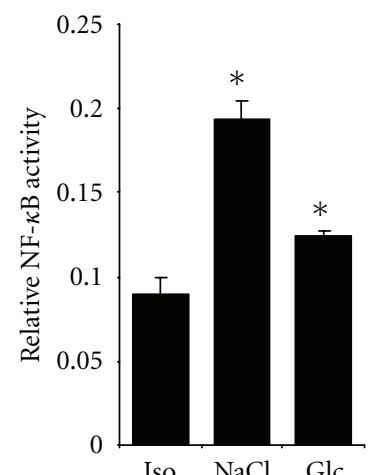

(a)

Glucose

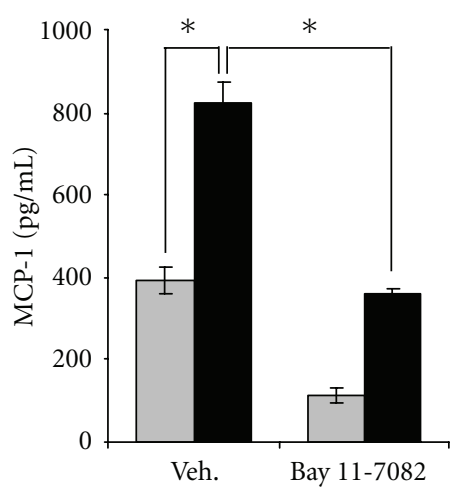

(c)

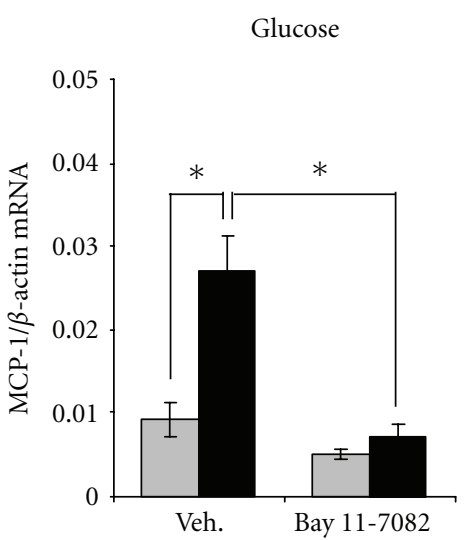

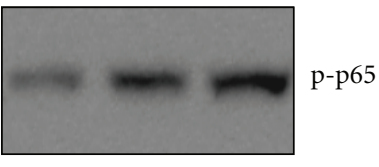

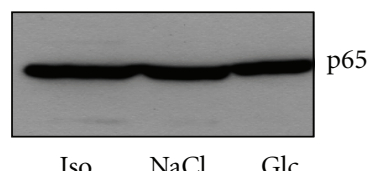

(b)

$\mathrm{NaCl}$
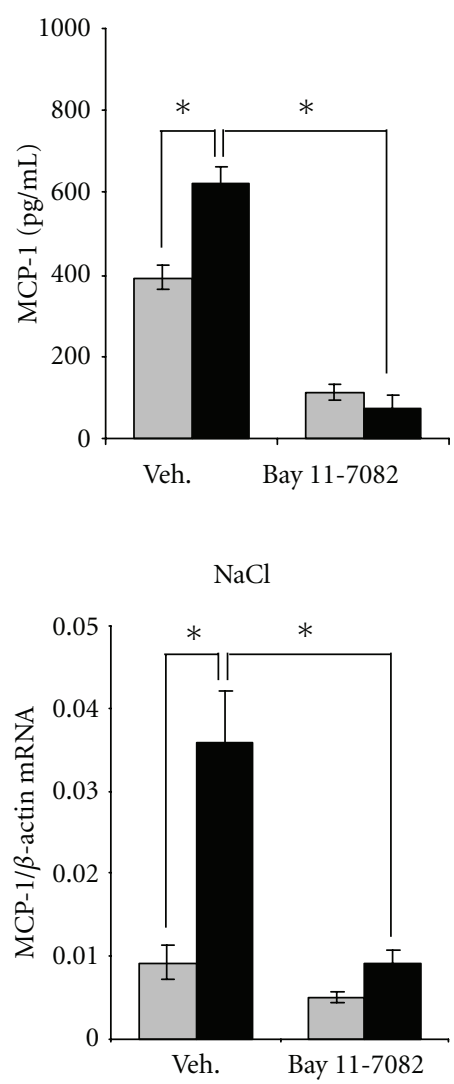

(d)

FIGURE 4: Role of NF- $\kappa \mathrm{B}$ in osmolality-induced MCP-1 expression. (a) Activation of NF- $\kappa \mathrm{B}$ by osmolality. Met5A cells were transiently transfected with a reporter construct in which the SEAP gene is under control of $\kappa \mathrm{B}$ sites. Cells were kept in isosmotic $\left(300 \mathrm{mosm} / \mathrm{kg} \mathrm{H}_{2} \mathrm{O}\right)$ medium or were exposed to hyperosmotic medium $\left(400 \mathrm{mosm} / \mathrm{kg} \mathrm{H}_{2} \mathrm{O}\right)$. Medium osmolality was elevated by addition of glucose or NaCl. After $24 \mathrm{~h}$, SEAP activity was measured as described in Section 2. Means \pm SEM for $n=4$; ${ }^{\#} P<0.05$ versus isosmotic control. (b) Phosphorylation of the p65 subunit by osmolality. Met5A cells were kept in isosmotic medium $\left(300 \mathrm{mosm} / \mathrm{kg} \mathrm{H} \mathrm{H}_{2} \mathrm{O}\right)$ or were exposed to hyperosmotic medium ( $400 \mathrm{mosm} / \mathrm{kg} \mathrm{H}_{2} \mathrm{O}$ ). Medium osmolality was elevated by addition of glucose or NaCl. After $16 \mathrm{~h}$, cells were processed for immunoblotting as described in Section 2. Abundance of phosphorylated p65 or whole p65 was tested using specific antibodies. A representative blot of three independent experiments is shown. (c) MCP-1 secretion. Met5A cells were preincubated for $1 \mathrm{~h}$ with the NF- $\kappa \mathrm{B}$ inhibitor Bay 11-7082 (5 $\mu \mathrm{M})$ or with vehicle DMSO only. Cells were kept in isosmotic (gray column; $300 \mathrm{mosm} / \mathrm{kg} \mathrm{H}{ }_{2} \mathrm{O}$ ) medium or were exposed to hyperosmotic medium (black column; 400 mosm $/ \mathrm{kg} \mathrm{H}_{2} \mathrm{O}$ ). Medium osmolality was elevated by addition of glucose or NaCl. After $24 \mathrm{~h}$, medium samples were collected and the concentration of MCP-1 in the cell culture supernatant was determined by ELISA as described in Section 2. Means \pm SEM for $n=4$ per point; ${ }^{*} P<0.05$. (d) MCP-1 transcription. Met5A cells were preincubated for $1 \mathrm{~h}$ with the NF- $\kappa$ B inhibitor Bay 11-7082 ( $5 \mu \mathrm{M}$ ) or with vehicle DMSO only. Cells were kept in isosmotic (gray column; $300 \mathrm{mosm} / \mathrm{kg} \mathrm{H} \mathrm{H}_{2} \mathrm{O}$ ) medium or were exposed to hyperosmotic medium (black column; $400 \mathrm{mosm} / \mathrm{kg} \mathrm{H} \mathrm{H}_{2} \mathrm{O}$ ). Medium osmolality was elevated by addition of glucose or $\mathrm{NaCl}$. After $24 \mathrm{~h}$, RNA was extracted from the cells and the abundance of MCP-1 mRNA transcript was determined by qRT-PCR as described in Section 2. Relative MCP-1 mRNA abundance was normalized to that of $\beta$-actin to correct for differences in RNA input. Means \pm SEM for $n=4$ per point; ${ }^{*} P<0.05$. 
NFAT5 expression probably due to stabilization of NFAT5 mRNA [31], by increased activity of the transactivation domain within the c-terminal portion of NFAT5 $[30,32]$, and by enhanced translocation from the cytoplasm to the nucleus $[33,34]$. Accordingly, hyperosmolality induced a significant upregulation of NFAT5 expression, increased nuclear translocation, and an increased activity of the transactivation domain also in Met5A cells.

We demonstrated activation of NFAT5 activity in response to hyperosmolality in Met5A cells using a TonEdriven reporter construct. Generally, the induction of NFAT5 activity by hyperosmolality in Met5A cells is relatively weak compared to kidney cells. With the same TonE-driven reporter construct, we observed an approximately 20-fold induction of NFAT5 activity in kidney cells [28], while in Met5A cells an approximately 2-fold induction occurred. Notably, maximal NFAT5 activation could be observed at about 400-450 mosm/ $/ \mathrm{kg} \mathrm{H}_{2} \mathrm{O}$ and declined rapidly at higher osmolalities, while in kidney cells maximal NFAT5 activation is achieved at osmolalities of $>500 \mathrm{mosm} / \mathrm{kg} \mathrm{H}_{2} \mathrm{O}$. In kidney cells, the nonreceptor tyrosine kinase focal adhesion kinase (FAK) is a positive regulator of NFAT5 activity under hyperosmotic conditions [35]; in mesothelial cells, high osmolalities, and especially high glucose concentrations, inhibit FAK [36], which may account for the decreasing NFAT5 activity at osmolalities $>450$ mosm $/ \mathrm{kg} \mathrm{H}_{2} \mathrm{O}$. Furthermore, the decreased NFAT5 activity may reflect a general decrease in cellular activity and perhaps cellular damage of mesothelial cells in response to high osmolalities [37]. In contrast, kidney cells have evolved effective mechanisms to maintain cellular activity even during hyperosmolality [38].

Met5A cells showed significant constitutive MCP-1 expression under isosmotic conditions. This basal expression appears to be largely independent of NFAT5, as NFAT5 knockdown had marginal effects on MCP-1 abundance at both the mRNA and protein levels under isosmotic conditions. In contrast, the pharmacological NF- $\kappa$ B inhibitor Bay 11-7082 significantly reduced not only hyperosmoticinduced MCP-1 expression but also basal expression under isosmotic conditions, indicating that basal NF- $\kappa \mathrm{B}$ activity under isosmotic conditions is necessary for basal MCP-1 expression. Involvement of $\mathrm{NF}-\kappa \mathrm{B}$ in regulation of osmolality-induced MCP-1 expression in mesothelial cells has been shown previously [27]. In Met5A cells, hyperosmolality activated a $\kappa \mathrm{B}$-driven reporter vector, especially in response to $\mathrm{NaCl}$ but also, to a lesser extent, in response to glucose. Accordingly, hyperosmolality induced phosphorylation of the p 65 subunit of NF- $\kappa$ B. A cooperation of NFAT 5 with NF$\kappa \mathrm{B}$ during osmolality-induced expression of cytokines has been already demonstrated in kidney cells [12]. In this study, the authors propose a model in which direct interaction of NFAT5 with the p65 subunit of NF- $\kappa \mathrm{B}$ increases binding of NF- $\kappa \mathrm{B}$ to $\kappa \mathrm{B}$ sites around $-2470 \mathrm{bp}$ and $-2440 \mathrm{bp}$ in the promoter region of MCP- 1 and enhances NF- $\kappa \mathrm{B}$ transcriptional activity under hypertonic conditions. However, the identification of a TonE site in the MCP-1 promoter region provides evidence that NFAT5 may stimulate MCP1 expression by two different mechanisms: first, by direct binding to the TonE site around $-190 \mathrm{bp}$ and activation of the transcriptional machinery; second, by interaction with $\mathrm{NF}-\kappa \mathrm{B}$ to enhance DNA binding and transcriptional activity of $\mathrm{NF}-\kappa \mathrm{B}$.

Interestingly, there were some differences in MCP-1 upregulation depending on whether medium osmolality was elevated by $\mathrm{NaCl}$ or glucose. Addition of $\mathrm{NaCl}$ to the medium had a stronger effect on NFAT5 abundance and activity and also on NF- $\kappa \mathrm{B}$ activity. Accordingly, MCP-1 mRNA abundance was more robustly induced by addition of $\mathrm{NaCl}$ compared to glucose. In contrast, the abundance of MCP1 protein in cell culture supernatants was significantly more enhanced by glucose than by $\mathrm{NaCl}$, indicating that posttranscriptional and/or posttranslational mechanisms further stimulate MCP-1 accumulation in the presence of glucose. A possible mechanism which may account for this observation could be protein glycosylation. MCP-1 can be modified by Oglycosylation and sialylation $[39,40]$, and this glycosylation enhances MCP-1 protein stability [41]. Since high glucose concentrations can enhance protein O-glycosylation [42, 43], it is conceivable that enhanced MCP-1 O-glycosylation contributes to the observed increased MCP-1 concentrations in cell culture supernatants under these conditions. However, since O-glycosylation of MCP-1 was not assessed in this study, this possibility remains to be established.

As mentioned above, hyperosmolality activated NFAT5 in mesothelial cells, regardless of whether glucose, $\mathrm{NaCl}$, or mannitol was used as the osmotic agent. This is not surprising since NFAT5 activation by these compounds has been shown before in various cell lines $[13,44,45]$. Several studies indicate that replacement of glucose as osmotic agent by icodextrin or amino acids may improve biocompatibility of PD fluids [46-48]. For future studies, it may be interesting to test the effects of icodextrin- or L-carnitine-induced hyperosmolality on NFAT5 activation and MCP-1 expression in mesothelial cells.

In T cells, NFAT5 has also been identified as a positive regulator for the expression of the proinflammatory cytokines TNF- $\alpha$ and lymphotoxin- $\beta$ (LT- $\beta$ ) in response to osmotic stress [49]. Since especially TNF- $\alpha$ is an important mediator of pathological alterations of the peritoneal membrane during CAPD [50], we also analyzed osmolality-induced expression of TNF- $\alpha$ and LT- $\beta$ in Met5A cells. However, we could not detect significant expression of TNF- $\alpha$ or LT- $\beta$ either under isosmotic or hyperosmotic conditions (data not shown). This is in accordance with the assumption that, during CAPD, TNF- $\alpha$ is synthesized preferentially by monocytes/macrophages [51] rather than mesothelial cells.

The gene encoding the chaperone HSP70 is another NFAT5-regulated gene [52]. Upregulation of HSP70 in response to PDF has been demonstrated in in vitro and in vivo models of $\mathrm{PD}[53,54]$ and confers increased resistance to PDF toxicity to mesothelial cells [55]. Knockdown of NFAT5 in Met5A cells also decreased HSP70 expression (data not shown), indicating that hyperosmolality-induced NFAT5 activity may also have an important role for cytoprotection of mesothelial cells during CAPD. 


\section{Conclusions}

Taken together, the present study indicates that the transcription factor NFAT5 is activated in response to high osmolalities in mesothelial cells and that this activation contributes to increased expression of MCP-1, probably in collaboration with NF- $\kappa \mathrm{B}$.

\section{Acknowledgments}

Work in the authors' laboratory was supported by grants from the Deutsche Forschungsgemeinschaft, the Deutsche Nierenstiftung, the Münchener Medizinische Wochenschrift, and by the Friedrich Baur Stiftung, Munich. The help of Maria-Luisa Fraek and critical reading of the paper by Dr. J. Davis are gratefully acknowledged.

\section{References}

[1] O. Devuyst, N. Topley, and J. D. Williams, "Morphological and functional changes in the dialysed peritoneal cavity: impact of more biocompatible solutions," Nephrology Dialysis Transplantation, vol. 17, supplement 3, pp. 12-15, 2002.

[2] C. W. McIntyre, "Update on peritoneal dialysis solutions," Kidney International, vol. 71, no. 6, pp. 486-490, 2007.

[3] J. D. Williams, K. J. Craig, N. Topley et al., "Morphologic changes in the peritoneal membrane of patients with renal disease," Journal of the American Society of Nephrology, vol. 13, no. 2, pp. 470-479, 2002.

[4] P. M. Ter Wee and F. J. Van Ittersum, "The new peritoneal dialysis solutions: friends only, or foes in part?" Nature Clinical Practice Nephrology, vol. 3, no. 11, pp. 604-612, 2007.

[5] T. O. Bender, J. Witowski, C. Aufricht et al., "Biocompatibility of a bicarbonate-buffered amino-acid-based solution for peritoneal dialysis," Pediatric Nephrology, vol. 23, no. 9, pp. 1537-1543, 2008.

[6] P. Fabbrini, M. Zareie, P. M. ter Wee, E. D. Keuning, R. H. J. Beelen, and J. van den Born, "Peritoneal exposure model in the rat as a tool to unravel bio(in)compatibility of PDF," Nephrology Dialysis Transplantation, vol. 21, no. 2, pp. ii8-ii11, 2006.

[7] T. Y. H. Wong, A. O. Phillips, J. Witowski, and N. Topley, "Glucose-mediated induction of TGF- $\beta 1$ and MCP- 1 in mesothelial cells in vitro is osmolality and polyol pathway dependent," Kidney International, vol. 63, no. 4, pp. 1404-1416, 2003.

[8] H. Miyakawa, S. K. Woo, S. C. Dahl, J. S. Handler, and H. M. Kwon, "Tonicity-responsive enhancer binding protein, a Rel-like protein that stimulates transcription in response to hypertonicity," Proceedings of the National Academy of Sciences of the United States of America, vol. 96, no. 5, pp. 2538-2542, 1999.

[9] W. Neuhofer and F. X. Beck, "Cell survival in the hostile environment of the renal medulla," Annual Review of Physiology, vol. 67, pp. 531-555, 2005.

[10] W. Y. Go, X. Liu, M. A. Roti, F. Liu, and S. N. Ho, "NFATS/ TonEBP mutant mice define osmotic stress as a critical feature of the lymphoid microenvironment," Proceedings of the $\mathrm{Na}$ tional Academy of Sciences of the United States of America, vol. 101, no. 29, pp. 10673-10678, 2004.

[11] W. Neuhofer, "Role of NFAT5 in inflammatory disorders associated with osmotic stress," Current Genomics, vol. 11, no. 8, pp. 584-590, 2010.
[12] I. Roth, V. Leroy, H. M. Kwon, P. Y. Martin, E. Féraille, and U. Hasler, "Osmoprotective transcription factor NFAT5/TonEBP modulates nuclear factor- $\kappa \mathrm{B}$ activity," Molecular Biology of the Cell, vol. 21, no. 19, pp. 3459-3474, 2010.

[13] R. Kojima, H. Taniguchi, A. Tsuzuki, K. Nakamura, Y. Sakakura, and M. Ito, "Hypertonicity-induced expression of monocyte chemoattractant protein-1 through a novel Cisacting element and MAPK signaling pathways," Journal of Immunology, vol. 184, no. 9, pp. 5253-5262, 2010.

[14] T. Yoshimura, N. Yuhki, S. K. Moore, E. Appella, M. I. Lerman, and E. J. Leonard, "Human monocyte chemoattractant protein-1 (MCP-1). Full length cDNA cloning, expression in mitogen-stimulated blood mononuclear leukocytes, and sequence similarity to mouse competence gene JE," FEBS Letters, vol. 244, no. 2, pp. 487-493, 1989.

[15] F. K. Li, A. Davenport, R. L. Robson et al., "Leukocyte migration across human peritoneal mesothelial cells is dependent on directed chemokine secretion and ICAM-1 expression," Kidney International, vol. 54, no. 6, pp. 2170-2183, 1998.

[16] Y. Jiang, D. I. Beller, G. Frendl, and D. T. Graves, "Monocyte chemoattractant protein-1 regulates adhesion molecule expression and cytokine production in human monocytes," Journal of Immunology, vol. 148, no. 8, pp. 2423-2428, 1992.

[17] B. J. Rollins, A. Walz, and M. Baggiolini, "Recombinant human MCP-1/JE induces chemotaxis, calcium flux, and the respiratory burst in human monocytes," Blood, vol. 78, no. 4, pp. 1112-1116, 1991.

[18] M. Gharaee-Kermani, E. M. Denholm, and S. H. Phan, "Costimulation of fibroblast collagen and transforming growth factor $\beta 1$ gene expression by monocyte chemoattractant protein-1 via specific receptors," The Journal of Biological Chemistry, vol. 271, no. 30, pp. 17779-17784, 1996.

[19] I. Inoshima, K. Kuwano, N. Hamada et al., "Anti-monocyte chemoattractant protein-1 gene therapy attenuates pulmonary fibrosis in mice," American Journal of Physiology, vol. 286, no. 5, pp. L1038-L1044, 2004.

[20] F. Marra, R. DeFranco, C. Grappone et al., "Increased expression of monocyte chemotactic protein-1 during active hepatic fibrogenesis: correlation with monocyte infiltration," American Journal of Pathology, vol. 152, no. 2, pp. 423-430, 1998.

[21] C. M. Lloyd, M. E. Dorf, A. Proudfoot, D. J. Salant, and J. C. Gutierrez-Ramos, "Role of MCP-1 and RANTES in inflammation and progression to fibrosis during murine crescentic nephritis," Journal of Leukocyte Biology, vol. 62, no. 5, pp. 676680, 1997.

[22] H. B. Zeyneloglu, L. M. Senturk, E. Seli, E. Oral, D. L. Olive, and A. Arici, "The role of monocyte chemotactic protein-1 in intraperitoneal adhesion formation," Human Reproduction, vol. 13, no. 5, pp. 1194-1199, 1998.

[23] H. B. Zeyneloglu, E. Seli, L. M. Senturk, L. S. Gutierrez, D. L. Olive, and A. Arici, "The effect of monocyte chemotactic protein 1 in intraperitoneal adhesion formation in a mouse model," American Journal of Obstetrics and Gynecology, vol. 179, no. 2, pp. 438-443, 1998.

[24] C. E. Visser, J. Tekstra, J. J. E. Brouwer-Steenbergen et al., "Chemokines produced by mesothelial cells: huGRO- $\alpha$, IP-10, MCP-1 and RANTES," Clinical and Experimental Immunology, vol. 112, no. 2, pp. 270-275, 1998.

[25] S. Takahashi, Y. Taniguchi, A. Nakashima et al., "Mizoribine suppresses the progression of experimental peritoneal fibrosis in a rat model," Nephron, vol. 112, no. 2, pp. e59-e69, 2009.

[26] S. K. Lee, B. S. Kim, W. S. Yang, S. B. Kim, S. K. Park, and J. S. Park, "High glucose induces MCP-1 expression partly via 
tyrosine kinase-AP-1 pathway in peritoneal mesothelial cells," Kidney International, vol. 60, no. 1, pp. 55-64, 2001.

[27] H. Matsuo, M. Tamura, N. Kabashima et al., "Prednisolone inhibits hyperosmolarity-induced expression of MCP-1 via NF- $\kappa \mathrm{B}$ in peritoneal mesothelial cells," Kidney International, vol. 69, no. 4, pp. 736-746, 2006.

[28] W. Neuhofer, D. Steinert, M. L. Fraek, and F. X. Beck, "Prostaglandin E2 stimulates expression of osmoprotective genes in MDCK cells and promotes survival under hypertonic conditions," Journal of Physiology, vol. 583, no. 1, pp. 287-297, 2007.

[29] C. Küper, D. Steinert, M. L. Fraek, F. X. Beck, and W. Neuhofer, "EGF receptor signaling is involved in expression of osmoprotective TonEBP target gene aldose reductase under hypertonic conditions," American Journal of Physiology, vol. 296, no. 5, pp. F1100-F1108, 2009.

[30] J. D. Ferraris, C. K. Williams, P. Persaud, Z. Zhang, Y. Chen, and M. B. Burg, "Activity of the TonEBP/OREBP transactivation domain varies directly with extracellular $\mathrm{NaCl}$ concentration," Proceedings of the National Academy of Sciences of the United States of America, vol. 99, no. 2, pp. 739-744, 2002.

[31] Q. Cai, J. D. Ferraris, and M. B. Burg, "High $\mathrm{NaCl}$ increases TonEBP/OREBP mRNA and protein by stabilizing its mRNA," American Journal of Physiology, vol. 289, no. 4, pp. F803-F807, 2005.

[32] M. Gallazzini, M. J. Yu, R. Gunaratne, M. B. Burg, and J. D. Ferraris, "c-Abl mediates high $\mathrm{NaCl}$-induced phosphorylation and activation of the transcription factor TonEBP/OREBP," The FASEB Journal, vol. 24, no. 11, pp. 4325-4335, 2010.

[33] S. C. Dahl, J. S. Handler, and H. M. Kwon, "Hypertonicityinduced phosphorylation and nuclear localization of the transcription factor TonEBP," American Journal of Physiology, vol. 280, no. 2, pp. C248-C253, 2001.

[34] C. E. Irarrazabal, M. Gallazzini, M. P. Schnetz et al., "Phospholipase $\mathrm{C}-\gamma 1$ is involved in signaling the activation by high $\mathrm{NaCl}$ of the osmoprotective transcription factor TonEBP/OREBP," Proceedings of the National Academy of Sciences of the United States of America, vol. 107, no. 2, pp. 906-911, 2010.

[35] W. Neuhofer, C. Küper, M.-L. Fraek et al., "Focal Adhesion Kinase regulates TonEBP transcriptional activity in response to osmotic stress," Acta Physiologica, vol. 201, supplement 682, article 248, 2011.

[36] M. Tamura, A. Osajima, S. Nakayamada et al., "High glucose levels inhibit focal adhesion kinase-mediated wound healing of rat peritoneal mesothelial cells," Kidney International, vol. 63, no. 2, pp. 722-731, 2003.

[37] H. Ha, M. R. Yu, H. N. Choi et al., "Effects of conventional and new peritoneal dialysis solutions on human peritoneal mesothelial cell viability and proliferation," Peritoneal Dialysis International, vol. 20, supplement 5, pp. S10-S18, 2001.

[38] C. Küper, F. X. Beck, and W. Neuhofer, "Osmoadaptation of mammalian cells - an orchestrated network of protective genes," Current Genomics, vol. 8, no. 4, pp. 209-218, 2007.

[39] Y. Jiang, A. J. Valente, M. J. Williamson, L. Zhang, and D. T. Graves, "Post-translational modification of a monocytespecific chemoattractant synthesized by glioma, osteosarcoma, and vascular smooth muscle cells," The Journal of Biological Chemistry, vol. 265, no. 30, pp. 18318-18321, 1990.

[40] P. Proost, S. Struyf, M. Couvreur et al., "Posttranslational modifications affect the activity of the human monocyte chemotactic proteins MCP-1 and MCP-2: identification of
MCP-2(6-76) as a natural chemokine inhibitor," Journal of Immunology, vol. 160, no. 8, pp. 4034-4041, 1998.

[41] P. Ruggiero, S. Flati, V. Di Cioccio et al., "Glycosylation enhances functional stability of the chemotactic cytokine CCL2," European Cytokine Network, vol. 14, no. 2, pp. 91-96, 2003.

[42] H. J. Goldberg, C. I. Whiteside, G. W. Hart, and I. G. Fantus, "Posttranslational, reversible O-glycosylation is stimulated by high glucose and mediates plasminogen activator inhibitor-1 gene expression and Sp1 transcriptional activity in glomerular mesangial cells," Endocrinology, vol. 147, no. 1, pp. 222-231, 2006.

[43] I. Han and J. E. Kudlow, "Reduced O glycosylation of Sp1 is associated with increased proteasome susceptibility," Molecular and Cellular Biology, vol. 17, no. 5, pp. 2550-2558, 1997.

[44] S. K. Woo, S. C. Dahl, J. S. Handler, and H. M. Kwon, "Bidirectional regulation of tonicity-responsive enhancer binding protein in response to changes in tonicity," American Journal of Physiology, vol. 278, no. 6, pp. F1006-F1012, 2000.

[45] B. Yang, A. D. Hodgkinson, P. J. Oates, M. K. Hyug, B. A. Millward, and A. G. Demaine, "Elevated activity of transcription factor nuclear factor of activated T-cells 5 (NFAT5) and diabetic nephropathy," Diabetes, vol. 55, no. 5, pp. 1450-1455, 2006.

[46] S. J. Davies, G. Woodrow, K. Donovan et al., "Icodextrin improves the fluid status of peritoneal dialysis patients: results of a double-blind randomized controlled trial," Journal of the American Society of Nephrology, vol. 14, no. 9, pp. 2338-2344, 2003.

[47] P. Freida, M. Wilkie, S. Jenkins, F. Dallas, and B. Issad, "The contribution of combined crystalloid and colloid osmosis to fluid and sodium management in peritoneal dialysis," Kidney International, vol. 73, no. 108, pp. S102-S111, 2008.

[48] N. M. Selby, J. Fialova, J. O. Burton, and C. W. McIntyre, "The haemodynamic and metabolic effects of hypertonic-glucose and amino-acid-based peritoneal dialysis fluids," Nephrology Dialysis Transplantation, vol. 22, no. 3, pp. 870-879, 2007.

[49] C. López-Rodríguez, J. Aramburu, L. Jin, A. S. Rakeman, M. Michino, and A. Rao, "Bridging the NFAT and NF- $\kappa$ B families: NFAT5 dimerization regulates cytokine gene transcription in response to osmotic stress," Immunity, vol. 15, no. 1, pp. 47$58,2001$.

[50] D. Zemel, G. C. M. Koomen, A. A. M. Hart, I. J. M. ten Berge, D. G. Struijk, and R. T. Krediet, "Relationship of TNF-alpha, interleukin-6, and prostaglandins to peritoneal permeability for macromolecules during longitudinal follow-up of peritonitis in continuous ambulatory peritoneal dialysis," Journal of Laboratory and Clinical Medicine, vol. 122, no. 6, pp. 686696, 1993.

[51] R. K. Mackenzie, C. J. Holmes, A. Moseley et al., "Bicarbonate/ lactate- and bicarbonate-buffered peritoneal dialysis fluids improve ex vivo peritoneal macrophage tnf $\alpha$ secretion," Journal of the American Society of Nephrology, vol. 9, no. 8, pp. 1499-1506, 1998.

[52] S. K. Woo, S. D. Lee, K. Y. Na, W. K. Park, and H. M. Kwon, "TonEBP/NFAT5 stimulates transcription of HSP70 in response to hypertonicity," Molecular and Cellular Biology, vol. 22, no. 16, pp. 5753-5760, 2002.

[53] K. Arbeiter, B. Bidmon, M. Endemann et al., "Induction of mesothelial HSP-72 upon in vivo exposure to peritoneal dialysis fluid," Peritoneal Dialysis International, vol. 23, no. 5, pp. 499-501, 2003. 
[54] C. Aufricht, M. Endemann, B. Bidmon et al., "Peritoneal dialysis fluids induce the stress response in human mesothelial cells," Peritoneal Dialysis International, vol. 21, no. 1, pp. 8588, 2001.

[55] B. Bidmon, M. Endemann, K. Arbeiter et al., "Overexpression of HSP-72 confers cytoprotection in experimental peritoneal dialysis," Kidney International, vol. 66, no. 6, pp. 2300-2307, 2004. 


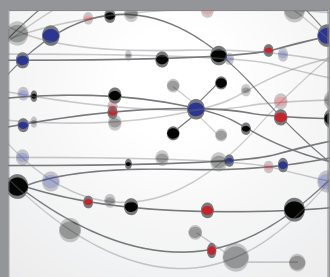

The Scientific World Journal
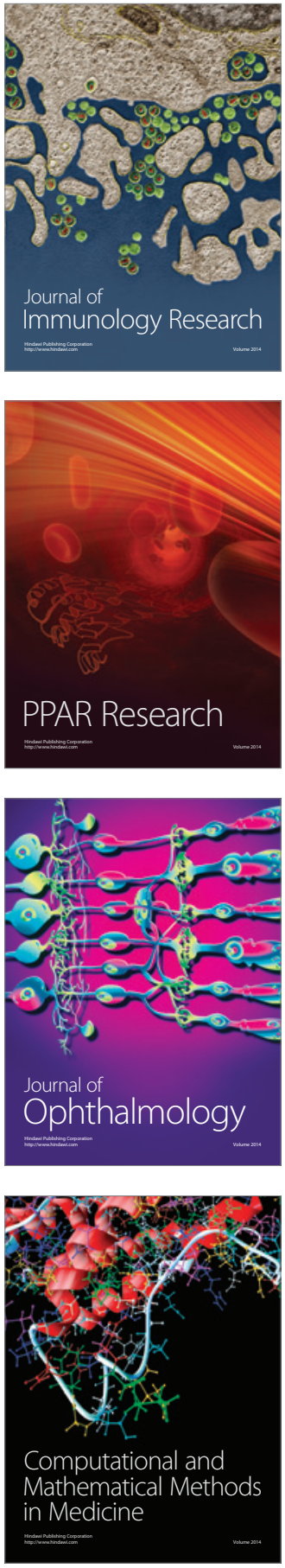

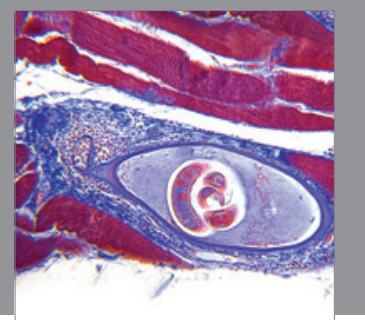

Gastroenterology

Research and Practice
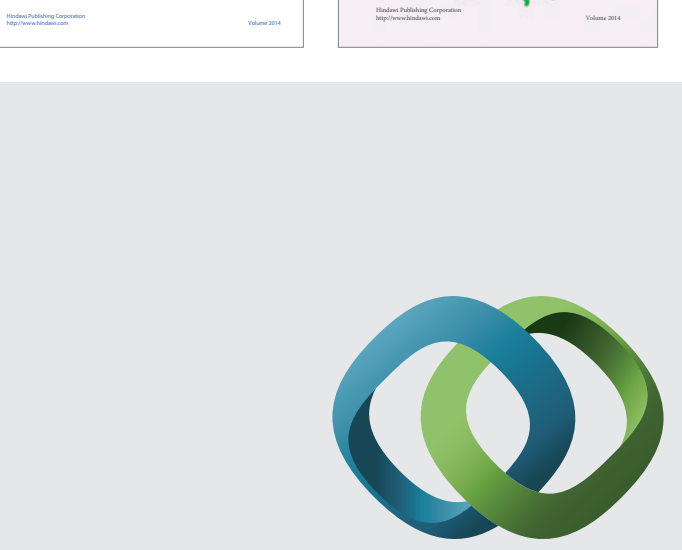

\section{Hindawi}

Submit your manuscripts at

http://www.hindawi.com
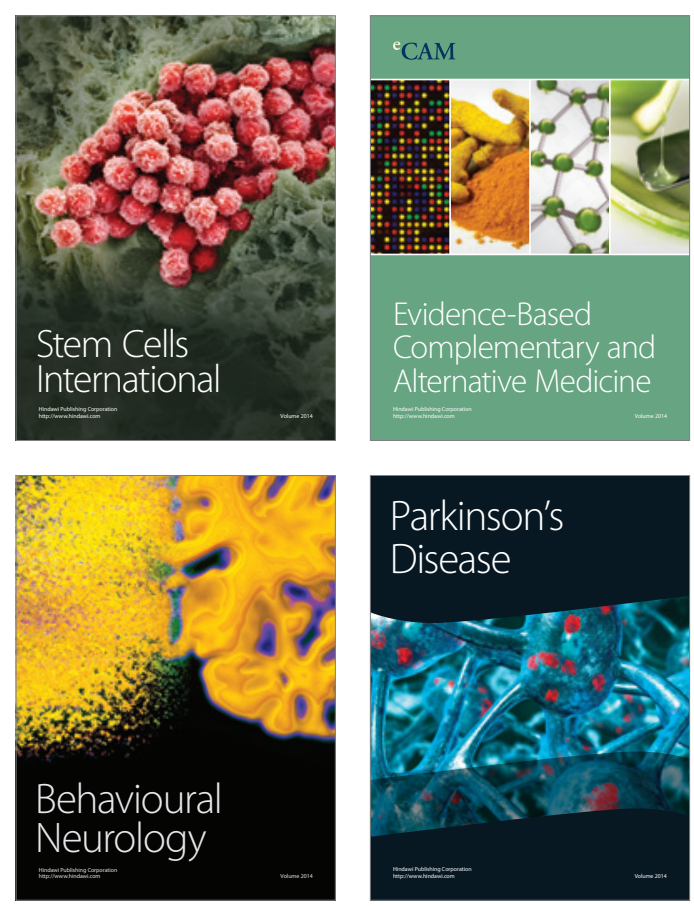

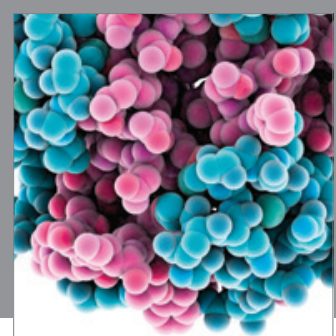

Journal of
Diabetes Research

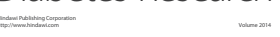

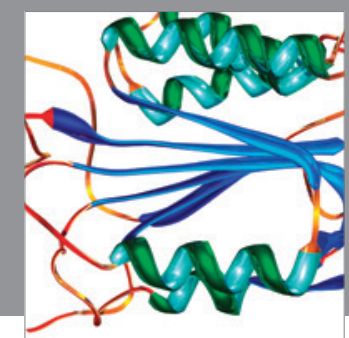

Disease Markers
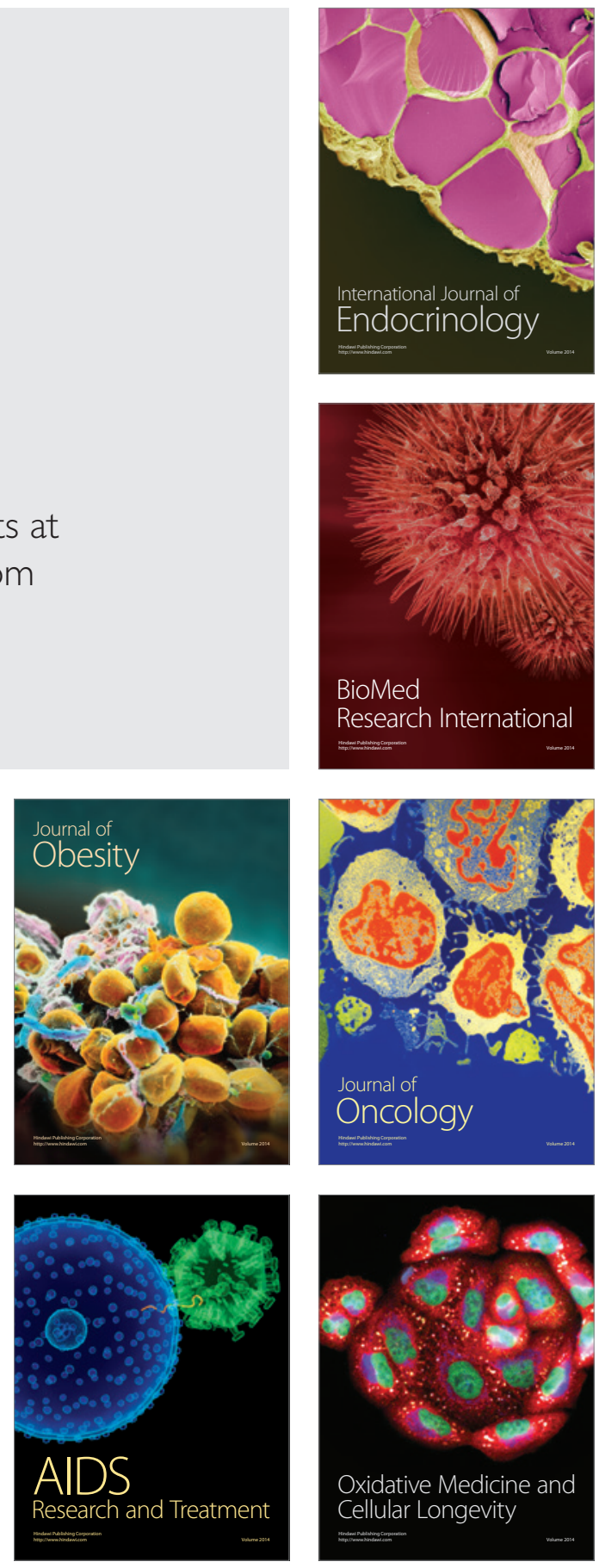